\title{
Sex Difference in the Relationship among Sufficiency of Vitamin, Metabolic Bone Markers, and Aging
}

\section{Masami Tanaka}

Department of Endocrinology, Metabolism and Nephrology, School of Medicine, Keio University 35 Shinanomachi, Shinjuku-ku, Tokyo 160-8582, Japan

"Corresponding authors: Masami Tanaka, Department of Endocrinology, Metabolism, and Nephrology, School of Medicine, Keio University 35 Shinanomachi, Shinjukuku, Tokyo 160-8582, Japan, Tel: +81-3-5363-3797; Fax: +81-3-3359-2745; E-mail: tana176k@keio.jp

Received date: August 30, 2017; Accepted date: September 06, 2017; Published date: September 10, 2017

Copyright: @ 2017 Tanaka M. This is an open-access article distributed under the terms of the Creative Commons Attribution License, which permits unrestricted use, distribution, and reproduction in any medium, provided the original author and source are credited.

\begin{abstract}
Objective: If bone absorption exceeds bone formation, bone mineral density decreases. If concentration of parathyroid hormone (PTH) is high and concentration of estrogen is low, bone absorption is accelerated. Deficiency in vitamin $\mathrm{D}$ and $\mathrm{K}$ leads to deterioration of bone quality, which leads to increased risk of fracture. We evaluated the relationship among age, sufficiency situation of vitamins, bone metabolic markers, and PTH according to man and woman in order to identify high risk group of fracture.
\end{abstract}

Methods: The subjects are 207 workers in Keio University who took staff medical examination. As markers evaluating the sufficiency of vitamins, 25-hydroxy vitamin $\mathrm{D}(25(\mathrm{OH}) \mathrm{D})$ and undercarboxylated osteocalcin (ucOC) were measured. Bone alkaline phosphatase (BAP), tartrate-resistant acid phosphatase (TRACP)-5b, intact PTH, calcium $(\mathrm{Ca})$ and phosphate $(\mathrm{P})$ were also measured. Then, correlation among $25(\mathrm{OH}) \mathrm{D}, \mathrm{ucOC}, \mathrm{BAP}, \mathrm{TRACP}-5 \mathrm{~b}$, intact $\mathrm{PTH}, \mathrm{Ca}, \mathrm{P}$, and age were investigated according to man and woman.

Results: Both in man and woman, there was a strong positive correlation among ucOC, BAP, and TRACP-5b. In both sexes, there was a negative correlation between both $\mathrm{Ca}$ and intact $\mathrm{PTH}$, and $\mathrm{P}$ and intact PTH. UcOC, BAP, and TRACP-5b correlated positively with age only in women.

Conclusions: Sex hormones might play small role in the correlation among ucOC, BAP, and TRACP-5b. On the other hand, in woman, estrogen deficiency might play important roles in the positive correlation between age and three parameters: ucOC, BAP, and TRACP-5b.

Keywords: Osteoporosis; Estrogen; Undercarboxylated osteocalcin; Bone alkaline phosphatase; Tartrate-resistant acid phosphatase -5b; 25hydroxy vitamin D; Parathyroid hormone

Abbreviations: 25(OH) D: 25-hydroxy vitamin D; ucOC Undercarboxylated osteocalcin; BAP: Bone alkaline phosphatase; TRACP-5b: Tartrate-resistant acid phosphatase-5b; Ca: Calcium; P: Phosphate; PTH: Parathyroid hormone

\section{Introduction}

Osteoporosis is the condition where fracture risk is increased in whole body. From before, it has been known that female gender, old age, and low bone mineral density [1] are the major risk factors for osteoporotic fractures.

Even after the bone grew up, bone absorption by osteoclast and bone formation by osteoblast are being repeated. This process of bone destruction and formation is called bone remodeling [2]. In other words, bone tissue is being renewed constantly. When the speed of bone renewal is high, it is called 'high bone turnover.' When this speed is low, it is called 'low bone turnover.' Under normal condition, the amount of bone absorption and bone formation is equal [3]. If bone absorption exceeds bone formation, bone mineral density decreases.

Estrogen suppresses bone absorption by increasing osteocytes and by decreasing osteoclasts. Accordingly, the decrease in secretion of estrogen leads to the decrease in bone mineral density, in other words, the decrease in bone mass [4]. Menopause is an important risk factor for fractures. Hormone replacement therapy with estrogen, which is a major therapy of menopausal disorders, also increases bone mass [5]. Parathyroid hormone (PTH) is another hormone which plays great roles in osteoporotic fracture. If the serum concentration of PTH is chronically high, bone absorption by osteoclast is accelerated and bone mass decreases.

In the National Institutes of Health Consensus Development Panel on Osteoporosis Prevention, Diagnosis, and Therapy convened in 2000 , osteoporosis was defined as a condition where bone strength is lowered by decreased bone mineral density and by deteriorated bone quality [6]. Bone strength is regulated by both bone mineral density and bone quality. Not only decreased bone mineral density, but also deteriorated bone quality increases the risk for fracture. It is speculated that the deficiency in vitamin $\mathrm{D}$ and $\mathrm{K}$ [7] leads to the deterioration of bone quality, which leads to increased risk of fracture.

Taking these backgrounds into consideration, we conducted this retrospective cohort study in order to identify the high risk group for fracture by evaluating the association among age, degree of vitamin $\mathrm{D}$ and $\mathrm{K}$ sufficiency, bone metabolic markers, and PTH levels according to man and woman. 
Page 2 of 4

\section{Methods}

We performed a retrospective cross-sectional study in 207 healthy Japanese (101 men and 106 women, age $54.8 \pm 7.2$ years). All of the subjects were the workers in Keio University who took staff medical examination. The study was approved by the ethics committee of Keio University School of Medicine and performed in accordance with the Declaration of Helsinki. Written informed consent was obtained from all participants.

At staff medical examination, we collected blood samples for the measurement of the serum concentration of 25-hydroxy vitamin D $(25(\mathrm{OH}) \mathrm{D})$, undercarboxylated osteocalcin (ucOC), bone alkaline phosphatase (BAP), tartrate-resistant acid phosphatase (TRACP)-5b, intact PTHcalcium $(\mathrm{Ca})$, and phosphate $(\mathrm{P}) .25(\mathrm{OH}) \mathrm{D}$ and ucOC were used as markers evaluating the sufficiency of vitamin $\mathrm{D}$ and $\mathrm{K}$, respectively. BAP and TRAC-5b were used as markers evaluating the bone formation and absorption, respectively. The correlation among $25(\mathrm{OH}) \mathrm{D}$, ucOC, BAP, TRACP-5b, intact PTH, Ca, P, and age were investigated comprehensively according to man and woman. Correlations between the two variables were assessed using Pearson's coefficient. All statistical analyses were conducted using the SPSS (version 17.0, Chicago, IL, USA). All data are expressed as mean \pm SD, and values of $\mathrm{p}<0.05$ (two-sided) were considered significant.

\section{Results}

The results were shown in Figure 1 (men) and Figure 2 (women). In man, the serum concentrations of ucOC, BAP, and TRACP-5b were 2.9 $\pm 1.6 \mathrm{ng} / \mathrm{mL}, 12.0 \pm 3.3 \mu \mathrm{g} / \mathrm{L}$, and $370.0 \pm 159.4 \mathrm{mU} / \mathrm{dL}$, respectively. In woman, the serum concentrations of ucOC, BAP, and TRACP-5b were $4.0 \pm 2.6 \mathrm{ng} / \mathrm{mL}, 12.6 \pm 4.5 \mu \mathrm{g} / \mathrm{L}$, and $316.4 \pm 125.6 \mathrm{mU} / \mathrm{dL}$, respectively. Both in man and woman, there were strong positive correlation among ucOC, BAP, and TRACP-5b (in man, ucOC and BAP, $r=0.39, p>0.0001$; $u c O C$ and TRACP-5b, $r=0.45, p<0.0001$; BAP and TRACP-5b, $\mathrm{r}=0.50, \mathrm{p}<0.0001$; in woman, ucOC and BAP, $\mathrm{r}=0.56$, $\mathrm{p}<0.0001$; ucOC and TRACP-5b, $\mathrm{r}=0.50, \mathrm{p}<0.0001 ; \mathrm{BAP}$ and TRACP-5b, $\mathrm{r}=0.63, \mathrm{p}<0.0001$ ).

In man, the serum concentrations of $\mathrm{Ca}, \mathrm{P}$, and intact $\mathrm{PTH}$ were 9.5 $\pm 0.3 \mathrm{mg} / \mathrm{dL}, 3.2 \pm 0.5 \mathrm{mg} / \mathrm{dL}$, and $38.3 \pm 14.0 \mathrm{pg} / \mathrm{mL}$, respectively. In women, the serum concentrations of $\mathrm{Ca}, \mathrm{P}$, and intact $\mathrm{PTH}$ were $9.5 \pm$ $0.3 \mathrm{mg} / \mathrm{dL}, 3.7 \pm 0.4 \mathrm{mg} / \mathrm{dL}$, and $38.1 \pm 14.0 \mathrm{pg} / \mathrm{mL}$, respectively. Both in man and woman, there were negative correlations between both $\mathrm{Ca}$ and $\mathrm{PTH}$, and $\mathrm{P}$ and intact $\mathrm{PTH}$ (in man: $\mathrm{Ca}$ and intact $\mathrm{PTH}, \mathrm{r}=-0.29$, $\mathrm{p}=0.0035$; $\mathrm{P}$ and intact $\mathrm{PTH}, \mathrm{r}=-0.29, \mathrm{p}=0.0037$; in women: $\mathrm{Ca}$ and intact PTH, $\mathrm{r}=-0.25, \mathrm{p}=0.0103$; $\mathrm{P}$ and intact $\mathrm{PTH}, \mathrm{r}=-0.41, \mathrm{p}<0.0001$ )

In woman, ucOC, BAP, and TRACP-5b were all positively correlated with age (ucOC, $r=0.29, p=0.0029$; BAP, $r=0.40, p<0.0001$; TRACP-5b, $\mathrm{r}=0.48, \mathrm{p}<0.0001)$. On the other hand, in man, all of ucOC, BAP, and TRACP-5b did not show significant correlation with age (ucOC, $\mathrm{r}=-0.054, \mathrm{p}=0.59$; BAP, $\mathrm{r}=0.024, \mathrm{p}=0.81$; TRACP-5b, $\mathrm{r}=0.037, \mathrm{p}=0.72$ )

The serum concentration of $25(\mathrm{OH}) \mathrm{D}$ were $28.8 \pm 7.1 \mathrm{ng} / \mathrm{mL}$ in man and $26.4 \pm 5.7 \mathrm{ng} / \mathrm{mL}$ in women. In man, 25(OH)D did not show correlation with age $(\mathrm{r}=0.09, \mathrm{p}=0.37)$. On the contrary, in woman, $25(\mathrm{OH}) \mathrm{D}$ showed a significant positive correlation with age $(\mathrm{r}=0.22$, $\mathrm{p}=0.025$ ).

\begin{tabular}{|c|c|c|c|c|c|c|c|c|}
\hline & $25(\mathrm{OH}) \mathrm{D}$ & UCOC & BAP & TRACP-5b & $\mathrm{Ca}$ & $\mathbf{P}$ & $\begin{array}{l}\text { Intact } \\
\text { PTH }\end{array}$ & Age \\
\hline $25(\mathrm{OH}) \mathrm{D}$ & & $\begin{array}{l}r=0.092 \\
p=0.36\end{array}$ & $\begin{array}{l}r=-0.040 \\
P=0.69\end{array}$ & $\begin{array}{l}r=0.081 \\
p=0.42\end{array}$ & $\begin{array}{l}r=-0.032 \\
P=0.75\end{array}$ & $\begin{array}{l}r=0.20 \\
P=0.044^{*}\end{array}$ & $\begin{array}{l}r=-0.17 \\
P=0.083\end{array}$ & $\begin{array}{l}r=0.09 \\
P=0.37\end{array}$ \\
\hline $\mathrm{ucOC}$ & $\begin{array}{l}r=0.092 \\
P=0.36\end{array}$ & & $\begin{array}{l}r=0.39 \\
p<0.0001 * *\end{array}$ & $\begin{array}{l}r=0.45 \\
p<0.0001 * *\end{array}$ & $\begin{array}{l}r=0.14 \\
P=0.16\end{array}$ & $\begin{array}{l}r=0.12 \\
P=0.24\end{array}$ & $\begin{array}{l}r=0.054 \\
P=0.59\end{array}$ & $\begin{array}{l}r=0.054 \\
P=0.59\end{array}$ \\
\hline BAP & $\begin{array}{l}r=-0.040 \\
P=0.69\end{array}$ & \begin{tabular}{|l|}
$r=0.39$ \\
$p<0.0001 * *$
\end{tabular} & & $\begin{array}{l}r=0.50 \\
p<0.0001 * *\end{array}$ & $\begin{array}{l}r=-0.18 \\
P=0.074\end{array}$ & $\begin{array}{l}\mathrm{r}=-0.26 \\
\mathrm{P}=0.013^{*}\end{array}$ & $\begin{array}{l}\mathrm{r}=0.21 \\
\mathrm{P}=0.038^{*}\end{array}$ & $\begin{array}{l}r=0.024 \\
P=0.81\end{array}$ \\
\hline TRACP-5b & $\begin{array}{l}r=0.081 \\
P=0.42\end{array}$ & \begin{tabular}{|l|}
$r=0.45$ \\
$p<0.0001 * *$
\end{tabular} & \begin{tabular}{|l|}
$r=0.50$ \\
$p<0.0001 * *$
\end{tabular} & & $\begin{array}{l}r=0.11 \\
P=0.27\end{array}$ & $\begin{array}{l}r=0.070 \\
P=0.49\end{array}$ & $\begin{array}{l}r=0.033 \\
P=0.75\end{array}$ & $\begin{array}{l}r=0.037 \\
P=0.72\end{array}$ \\
\hline $\mathrm{Ca}$ & $\begin{array}{l}r=-0.032 \\
P=0.75\end{array}$ & $\begin{array}{l}r=-0.14 \\
P=0.16\end{array}$ & $\begin{array}{l}r=-0.18 \\
P=0.074\end{array}$ & $\begin{array}{l}r=-0.11 \\
P=0.27\end{array}$ & & $\begin{array}{l}r=0.10 \\
P=0.31\end{array}$ & $\begin{array}{l}\mathrm{r}=0.29 \\
\mathrm{P}=0.0035^{* *}\end{array}$ & $\begin{array}{l}r=0.023 \\
P=0.82\end{array}$ \\
\hline $\mathbf{P}$ & $\begin{array}{l}r=0.20 \\
P=0.044^{*}\end{array}$ & $\begin{array}{l}r=0.12 \\
P=0.24\end{array}$ & $\begin{array}{l}r=-0.26 \\
P=0.013^{*}\end{array}$ & $\begin{array}{l}r=0.070 \\
P=0.49\end{array}$ & & & $\begin{array}{l}\mathrm{r}=0.29 \\
\mathrm{P}=0.0037 * *\end{array}$ & $\begin{array}{l}r=0.078 \\
P=0.44\end{array}$ \\
\hline $\begin{array}{c}\text { Intact } \\
\text { PTH }\end{array}$ & $\begin{array}{l}\mathrm{r}=-0.17 \\
\mathrm{P}=0.083\end{array}$ & $\begin{array}{l}r=0.054 \\
p=0.59\end{array}$ & $\begin{array}{l}r=0.21 \\
P=0.038^{*}\end{array}$ & $\begin{array}{l}r=0.033 \\
P=0.75\end{array}$ & $\begin{array}{l}r=0.29 \\
p=0.0035 * *\end{array}$ & $\begin{array}{l}r=-0.29 \\
P=0.0037 * *\end{array}$ & & $\begin{array}{l}r=0.085 \\
P=0.40\end{array}$ \\
\hline Age & $\begin{array}{l}r=0.09 \\
P=0.37\end{array}$ & $\begin{array}{l}r=0.054 \\
p=0.59\end{array}$ & $\begin{array}{l}r=0.024 \\
P=0.81\end{array}$ & $\begin{array}{l}r=0.037 \\
P=0.72\end{array}$ & $\begin{array}{l}r=0.023 \\
P=0.82\end{array}$ & $\begin{array}{l}r=-0.078 \\
P=0.44\end{array}$ & $\begin{array}{l}r=0.085 \\
P=0.40\end{array}$ & \\
\hline
\end{tabular}

Figure 1: The correlation among age, degree of vitamin $\mathrm{D}$ and $\mathrm{K}$ sufficiency, bone metabolic markers, PTH levels, calcium, and phosphate in $\operatorname{man}\left({ }^{*}: \mathrm{p}<0.05,{ }^{* *}: \mathrm{p}<0.01\right)$.

\begin{tabular}{|c|c|c|c|c|c|c|c|c|}
\hline & $25(\mathrm{OH}) \mathrm{D}$ & ucOC & BAP & TRACP-5b & $\mathrm{Ca}$ & $\mathbf{P}$ & $\begin{array}{l}\text { Intact } \\
\text { PTH }\end{array}$ & Age \\
\hline $25(\mathrm{OH}) \mathrm{D}$ & & $\begin{array}{l}r=0.079 \\
P=0.42\end{array}$ & $\begin{array}{l}r=0.021 \\
P=0.83\end{array}$ & $\begin{array}{l}r=0.081 \\
P=0.41\end{array}$ & $\begin{array}{l}r=0.10 \\
P=0.30\end{array}$ & $\begin{array}{l}r=0.11 \\
P=0.26\end{array}$ & $\begin{array}{l}r=-0.14 \\
P=0.15\end{array}$ & $\begin{array}{l}r=0.22 \\
P=0.025 *\end{array}$ \\
\hline ucOC & $\begin{array}{l}r=0.079 \\
P=0.42\end{array}$ & & $\begin{array}{l}r=0.56 \\
p<0.0001 * *\end{array}$ & \begin{tabular}{|l|}
$r=0.50$ \\
$p<0.0001 * *$
\end{tabular} & $\begin{array}{l}r=0.20 \\
P=0.038^{*}\end{array}$ & $\begin{array}{l}r=0.10 \\
P=0.30\end{array}$ & $\begin{array}{l}r=0.092 \\
P=0.35\end{array}$ & $\begin{array}{l}r=0.29 \\
P=0.0029 * *\end{array}$ \\
\hline BAP & $\begin{array}{l}r=0.021 \\
P=0.83\end{array}$ & $\begin{array}{l}r=0.56 \\
p<0.0001 * *\end{array}$ & & $\begin{array}{l}r=0.63 \\
p<0.0001 * *\end{array}$ & $\begin{array}{l}r=0.36 \\
P<0.001 * *\end{array}$ & $\begin{array}{l}r=0.045 \\
P=0.65\end{array}$ & $\begin{array}{l}r=0.047 \\
P=0.64\end{array}$ & $\begin{array}{l}r=0.40 \\
p<0.0001^{* *}\end{array}$ \\
\hline TRACP-5b & $\begin{array}{l}r=0.081 \\
P=0.41\end{array}$ & $\begin{array}{l}r=0.50 \\
p<0.0001 * *\end{array}$ & $\begin{array}{l}r=0.63 \\
p<0.0001 * *\end{array}$ & & $\begin{array}{l}r=0.25 \\
p<0.0086^{* *}\end{array}$ & $\begin{array}{l}r=0.12 \\
\mathrm{P}=0.20\end{array}$ & $\begin{array}{l}r=-0.083 \\
P=0.40\end{array}$ & $\begin{array}{l}r=0.48 \\
p<0.0001^{* *}\end{array}$ \\
\hline $\mathrm{Ca}$ & $\begin{array}{l}r=0.10 \\
P=0.30\end{array}$ & $\begin{array}{l}\mathrm{r}=0.20 \\
\mathrm{P}=0.038^{*}\end{array}$ & $\begin{array}{l}r=0.36 \\
p<0.001 * *\end{array}$ & $\begin{array}{l}\mathrm{r}=0.25 \\
\mathrm{P}<0.0086^{* *}\end{array}$ & & $\begin{array}{l}r=-0.074 \\
P=0.45\end{array}$ & $\begin{array}{l}r=0.25 \\
P=0.0103^{*}\end{array}$ & $\begin{array}{l}r=0.30 \\
P=0.0019 * *\end{array}$ \\
\hline $\mathbf{P}$ & $\begin{array}{l}r=0.11 \\
P=0.26\end{array}$ & $\begin{array}{l}r=0.10 \\
P=0.30\end{array}$ & $\begin{array}{l}r=0.045 \\
P=0.65\end{array}$ & $\begin{array}{l}\mathrm{r}=0.12 \\
\mathrm{P}=0.20\end{array}$ & $\begin{array}{l}r=-0.074 \\
P=0.45\end{array}$ & & $\begin{array}{l}r=-0.41 \\
p<0.0001 * *\end{array}$ & $\begin{array}{l}r=0.20 \\
P=0.043^{*}\end{array}$ \\
\hline $\begin{array}{l}\text { Intact } \\
\text { PTH }\end{array}$ & $\begin{array}{l}r=0.14 \\
P=0.15\end{array}$ & $\begin{array}{l}r=0.092 \\
p=0.35\end{array}$ & $\begin{array}{l}r=0.047 \\
P=0.64\end{array}$ & $\begin{array}{l}r=-0.083 \\
P=0.40\end{array}$ & $\begin{array}{l}r=0.25 \\
P=0.0103^{*}\end{array}$ & $\begin{array}{l}r=-0.41 \\
p<0.0001 * *\end{array}$ & & $\begin{array}{l}r=-0.057 \\
P=0.57\end{array}$ \\
\hline Age & $\begin{array}{l}r=0.22 \\
P=0.025 *\end{array}$ & $\begin{array}{l}\mathrm{r}=0.29 \\
\mathrm{P}=0.0029 * *\end{array}$ & $\begin{array}{l}r=0.40 \\
p<0.0001 * *\end{array}$ & $\begin{array}{l}r=0.48 \\
p<0.0001 * *\end{array}$ & $\begin{array}{l}r=0.30 \\
P=0.0019 * *\end{array}$ & $\begin{array}{l}r=0.20 \\
P=0.043 *\end{array}$ & $\begin{array}{l}r=-0.057 \\
P=0.57\end{array}$ & \\
\hline
\end{tabular}

Figure 2: The correlation among age, degree of vitamin $\mathrm{D}$ and $\mathrm{K}$ sufficiency, bone metabolic markers, PTH levels, calcium, and phosphate in woman $\left({ }^{*}: \mathrm{p}<0.05,{ }^{* *}: \mathrm{p}<0.01\right)$. 


\section{Discussion}

In the present study, there was a strong positive correlation among ucOC, BAP and TRACP-5b in both sexes. In the subjects of this study, BAP, which is a bone formation marker, correlated positively with TRACP-5b, which is a bone absorption marker. This means that bone turnover (bone formation and bone absorption) was well balanced. When bone formation and absorption lose balance and bone absorption exceeds bone formation, bone mass decreases and fracture risk increases. Therefore, bisphosphonate which inhibit bone absorption and synthesized human PTH which stimulate bone formation elicit remarkable effects of increasing bone mineral density and prohibiting fracture. On the other hand, high concentration of ucOC reflects insufficient vitamin $\mathrm{K}$ status, which deteriorates bone quality. ucOC was reported to be an important predictive factor of femoral neck fracture [8]Moreover, it was reported that the administration of vitamin $\mathrm{K}$ decreased the concentration of ucOC and showed the protective effect against fracture [9]. Because there were no reports that ucOC and bone mineral density was correlateducOC is thought to be a marker of bone quality, not of bone mineral density. Although the mechanisms underlying the correlations among ucOC, BAP, and TRACP-5b are unclear, sex hormones might not be deeply involved because these correlations are seen in both sexes.

In the present study, in both man and woman, intact PTH was inversely correlation with both $\mathrm{Ca}$ and $\mathrm{P}$. This observation might indicate that the bone metabolism is regulated by PTH and that sex hormones are not involved strongly. Although it is not significant, there was a tendency that intact PTH inversely correlated with $25(\mathrm{OH}) \mathrm{D}$ in both man $(\mathrm{r}=-0.17, \mathrm{p}=0.083)$ and woman $(\mathrm{r}=-0.14$, $\mathrm{p}=0.15$ ). This observation also reflects the regulatory mechanisms in a living body that when serum Ca concentration is low, PTH secretion increases in order to raise the concentration of vitamin $\mathrm{D}$, then $\mathrm{Ca}$ absorption from the gut increases [10]. If PTH is secreted continuously and excessively, bone absorption exaggerates and bone absorption is stimulated [11]. On the contrary, when PTH is administered intermittently, bone formation is stimulated. That is the reason why synthesized human PTH is applied for the injectable medicine for the patients with severe osteoporosis [12].

The sufficiency degree of vitamin $\mathrm{D}$ is judged by the serum concentration of $25(\mathrm{OH}) \mathrm{D}$. Two standards, which are less than 20 $\mathrm{ng} / \mathrm{mL}$ and less than $30 \mathrm{ng} / \mathrm{mL}$, are frequently used as reference ranges as vitamin $\mathrm{D}$ deficiency [13]. The average serum concentration of $25(\mathrm{OH}) \mathrm{D}$ of the subjects in this study was less than $30 \mathrm{ng} / \mathrm{mL}$ in both sexes $(28.8 \mathrm{ng} / \mathrm{mL}$ in man and $26.4 \mathrm{ng} / \mathrm{mL}$ in woman). This result indicates that among medical checkup examinee that looks apparently healthy, vitamin D deficiency is identified very frequently. Vitamin D deficiency leads to the decrease in $\mathrm{Ca}$ absorption from the gut. When $\mathrm{Ca}$ absorption decreases and serum Ca concentration declines, PTH secretion is stimulated and bone absorption is accelerated, then finally leading to the decrease in bone mineral density and the development of osteoporosis. Recently humans eat more meat, less fish, and avoid ultraviolet light more than necessary, all of which accelerate vitamin $\mathrm{D}$ deficiency. It is pointed out that Japanese food is nutritionally wellbalanced but contains small amount of Ca. This might be one of the reasons why the participants of this study showed low concentration of $25(\mathrm{OH})$ D. Taking enough Ca through food is effective for the improvement of vitamin D sufficiency degree.

It is interesting that $\mathrm{ucOC}, \mathrm{BAP}$, and TRACP-5b positively correlated with aging in woman but not in man. This observation might indicate that vitamin $\mathrm{K}$ deficiency is more common in old women than in young women, because high concentration of ucOC reflects the insufficient effect of vitamin $\mathrm{K}$ on bone. On the other hand, increased concentration of BAP and TRACP-5b might reflect the accelerated bone turnover associated with aging. It is reported that increased value of bone metabolism markers can be a predictive factor for fracture in the future [14] and that this predictive ability is independent of bone mineral density [15]. As the average of the female participants of this study was as old as 50.3 years, it was suggested that many postmenopausal women were included. Estrogen deficiency greatly contributes to the pathophysiology of postmenopausal osteoporosis. It is pointed out that estrogen deficiency might not only stimulate bone absorption, but also inhibit bone formation through increasing oxidative stress [16] Therefore, selective estrogen receptor modulator (SERM) is expected as a medicine which can prevent fracture due to postmenopausal osteoporosis and it is actually eliciting this excellent effect in clinical practice.

This study has several limitations. This is a retrospective, crosssectional study in a small number of the subjects. Therefore, cause and effect relationships cannot be clarified, and the possibility of bias cannot be excluded. In addition, this research is limited by its single source of participants. All participants are workers from the same university. Therefore, the results of this study may not be applicable to the general population.

\section{Conclusions}

In our study, it is suggested that the fracture risk can be increased with aging more easily in woman than in man. In order to prevent fracture in aged woman, the administration of estrogen or SERM, and the ingestion of sufficient vitamin $\mathrm{K}$ and $\mathrm{D}$ might be effective.

\section{References}

1. Marshall D, Johnell O, Wedel H (1996) Meta-analysis of how well measures of bone mineral density predict occurrence of osteoporotic fractures. BMJ 312: 1254-1259.

2. Frost HM (1964) Dynamics of bone remodeling. Bone Biodyn: 315-333.

3. Raisz LG (2005) Pathogenesis of osteoporosis: concept, conflicts, and prospects. J Clin Invest 155: 3318-3325.

4. Zebaze RM, Ghasem-Zadeh A, Bohte A, Iuliano-Burns S, Mirams M, et al. (2010) Intracortical remodeling and porosity in the distal radius and postmortem femurs of women: a cross-sectional study. Lancet 375: 1729-1736.

5. Doren M, Nilsson JA, Johnell O (2003) Effects of specific postmenopausal hormone therapies on bone mineral density in post-menopausal women; a meta-analysis. Hun Reprod 18: 1737-1746.

6. NIH Consensus Development Panel on Osteoporosis Prevention, Diagnosis, and Therapy (2001) Osteoporosis prevention, diagnosis, and therapy. JAMA 285: 785-795.

7. Liu G, Peacock CK (1998) Age-related changes in serum undercarboxylated osteocalcin ant its relationship with bone density, bone quality, and hip fracture. Calcif Tissue Int 62: 286-289.

8. Vergnaud P, Garnero P, Meunier PJ, Bréart G, Kamihagi K, et al. (1997) Undercarboxylated osteocalcin measured with a specific immunoassay predicts hip fracture in elderly women. The EPIDOS study. J Clin Endocrinol Metab 82: 719-724.

9. Shiraki M, Shiraki Y, Aoki C, Miura M (2000) Vitamin K2 (menatetrenone) effectively prevents fractures and sustains lumbar bone mineral density in osteoporosis. J Bone Miner Res 15: 515-521.

10. Potts JT, Gardella TJ (2007) Progress, paradox, and potential: parathyroid hormone research over five decades. Ann N Y Acad Sci 1117: 196-208. 
Citation: Tanaka M (2017) Sex Difference in the Relationship among Sufficiency of Vitamin, Metabolic Bone Markers, and Aging. J Diabetes Metab 8: 758. doi:10.4172/2155-6156.1000758

Page 4 of 4

11. Bilezikian JP (2012) Primary hyperaldosteronism. Endocr Pract 18: 781-790.

12. Larsson S, Fazzalari NL (2014) Anti-osteoporosis therapy and fracture healing. Arch Orthop Trauma Surg 134: 291-297.

13. Holick MF, Binkley NC, Bischoff-Ferrari HA, Gordon CM, Hanley DA, et al. (2011) Evaluation, treatment, and prevention of vitamin D deficiency: an Endocrine Society clinical practice guideline. J Clin Endocrinol Metab 96: 1911-1930.

14. Ivaska KK, Gerdhem P, Vaänänen HK, Akesson K, Obrant KJ (2010) Bone turnover markers and prediction of fracture: a prospective follow-up study of 1040 elderly women for a mean of 9 years. J Bone Miner Res 25: 393-403

15. Gerdhem P, Ivaska KK, Alatalo SL (2004) Biochemical markers of bone metabolism and prediction of fracture in elderly women. J Bone Miner Res 19: 386-393.

16. Walsh BW, Paul S, Wild RA (2000) The effects of hormone replacement therapy and raloxifene on C-reactive protein and homocysteine in healthy postmenopausal women: a randomized, controlled trial. J Clin Endocrinol Metab 85: 214-218. 